\title{
BRINGING THE MILITARY BACK IN: MILITARY EXPENDITURES AND ECONOMIC GROWTH 1990 TO $2003{ }^{1}$
}

\author{
Jeffrey Kentor \\ Department of Sociology \\ University of Utah \\ kentor@soc.utah.edu \\ Edward Kick \\ Department of Sociology and Anthropology \\ North Carolina State University \\ elkick@sa.ncsu.edu
}

\begin{abstract}
After the "peace bonus" era, global military expenditures have escalated sharply despite some worldwide declines in military personnel. Theories on the economic impacts of the military institution and escalated military spending greatly differ and include arguments that they either improve domestic economic performance or crowd out growth-inducing processes. Empirical findings on this matter are inconclusive, in part due to a failure to disentangle the various dimensions of military expenditures. We further suggest that modern sociology's relative inattention to such issues has contributed to these shortcomings. We explore a new dimension of military spending that clarifies this issue-military expenditures per soldier — which captures the capital intensiveness of a country's military organization. Our cross-national panel regression and causal analyses of developed and less developed countries from 1990 to 2003 show that military expenditures per soldier inhibit the growth of per capita GDP, net of control variables, with the most pronounced effects in least developed countries. These expenditures inhibit national development in part by slowing the expansion of the labor force. Labor-intensive militaries may provide a pathway for upward mobility, but comparatively capital-intensive military organizations limit entry opportunities for unskilled and under- or unemployed people. Deep investments in military hardware also reduce the investment capital available for more economically productive opportunities. We also find that arms imports have a positive effect on economic growth, but only in less developed countries.
\end{abstract}

\footnotetext{
${ }^{1}$ An earlier version of this paper was presented at the $47^{\text {th }}$ Annual Convention of the International Studies Association, San Diego, CA: March, 2006. Direct all correspondence to Jeffrey Kentor, Department of Sociology, University of Utah, Salt Lake City, UT 84112 (Kentor@soc.utah.edu).
}

Copyright @2008, Journal of World-Systems Research, Volume XIV, Number 2, Pages 142-172 ISSN 1076-156X 


\section{INTRODUCTION}

Research on the "military", broadly construed, has been largely absent from the major general sociological journals in the recent past. Since the beginning of this century, our search of the literature identified only 3 articles in the three primary journals (American Sociological Review, American Journal of Sociology, Social Forces) with the term "military" in the title. ${ }^{2}$ (Lundquist 2004, 2008; Teachman 2004). In the previous decade (1990-1999), we found a total of 7 publications on the military in these journals, and only 3 articles in the 1980s. There is, of course, an ASA journal dedicated to the military; The Journal of Political and Military Sociology. However, articles published in this journal appear have little impact on the discipline, as evidenced by an average impact factor of approximately 0.053 for 2005 through 2007 (Journal Citation Reports 2008). This is somewhat surprising given the enormous direct and indirect impact the military has had on society throughout history. There are many possible explanations for the dearth of publications in this area, including the end of the draft, a general aversion of many sociologists to the military, and the "closed" nature of the military establishment. Whatever the reason, we believe it to be a significant omission. The current Iraq War highlights some of the direct and indirect impacts of the military establishment, with thousands dead and many more thousands wounded, massive population dislocations, and billions of dollars spent. It is estimated that the military now consumes between $21 \%$ and $50 \%$ of the annual U.S. budget, with estimates varying principally due to data source (e.g., U.S. Arms Control and Disarmament Agency [ACDA] versus Stockholm Peace Research Institute) and the operationalization of the construct "military expenditures" (e.g., military personnel, operations and maintenance, research and development, international security, homeland security versus retirees pay, among others). But the more ubiquitous aspects of the military are also significant globally in terms of military aid, weapons sales, etc. Though it may not be apparent, the military impacts many aspects of our social, political, and economic lives.

We draw attention to one aspect of the military - its increasing capital intensiveness - and its impact the labor force and economic development. We will argue (with support from empirical findings) that the military establishment's growing reliance on material over "boots on the ground" limits its traditional role as employer of last resort and pathway of upward mobility for the uneducated and unskilled in our society. This inhibits the growth of the labor force, which slows economic growth. In raising these issues we also hope to bring the military back into focus as a significant actor that is a legitimate area of study for mainstream sociology.

\section{Military Expenditures and Economic Development}

Coupled with the end of the Cold War and the emergence of a new "neoliberal order," hopes were raised globally for a peace dividend" that could lead to economic growth and improvements in social well being. World military expenditures in constant dollars declined significantly in the 1990s despite advances in military technology, as the total armed forces in the world dropped

\footnotetext{
${ }^{2}$ Four additional articles were published in these journals that included some aspect of military in their analyses as control variables (e.g. Jenkins and Scalan 2001). While we do not claim that in its many aspects militarism has uniformly and monumentally increased in recent times, it is surprising that it is so relatively understudied by sociologists.
} 
from 28,300,000 to 22,3000,000 (ACDA 2000:61). But world military expenditures began to rise again in the late 1990 s and escalated to $\$ 956$ billion in 2003, an $18 \%$ increase in just two years (SIPRI 2004).

For many the logic is clear: had global reductions in military expenditures been sustained, they could have promoted near-universal improvements in economic growth and human welfare; thus, the "guns or butter" choice is an unambiguous one favoring reductions in military spending (Kourvetaris 1991). Yet militarization-economic growth linkages are complex (Scanlan and Jenkins 2001) and some contend that "guns and butter" better describes the empirics of this relationship (Benoit 1973; Firebaugh and Beck 1994). The estimated 2007 military budget inclusive of military personnel, military construction, and other defense-related activities was over $\$ 571$ billion. This figure makes other governmental expenditures pale by comparison. For example, despite the national determination of an energy and environmental crises, when taken together the amount the government has earmarked for these functions is less than 7 percent of that which is put into the military (Budget of the U.S. Government 2008).

Questions over the military impact extend well beyond the U.S., Western Europe and global powers such as China and Russia, who also have escalated their military outlays in recent years. Indeed the military is the largest single component in most government bureaucracies in developing nation-states. Close to two-thirds of the world's soldiers now are in developing countries alone. Even with the global spread of democracy in over sixty developing countries the military institution exercises significant executive, judicial and legislative power over the citizenry (Sivard 1993).

When these circumstances are coupled with post World War II evidence from Japan and West Germany showing favorable connections between de-militarization and economic growth, questions about the influence of military spending on economic advance are germane. In ensuing discussions we develop competing theorizations on the impacts of the military institution and military expenditures on growth and review the evidence. Theory and evidence suggest the need for analyses that decompose military spending effects on growth, with a focus on disentangling the impacts of military spending on personnel versus equipment as a key axis for judging these effects.

\section{LITERATURE REVIEW ${ }^{3}$}

\section{The Evolution of the Modern Military Establishment}

Tilly (1994) argues that the current inter-state system is the result of a merging of coercive and economic power between A.D. 1000 and 1800. Prior to this time, economic and coercive, or military, power were separate. Political units, such as states, feudal areas and empires, were essentially containers of coercive power, used this power to acquire the necessary goods, and people, to maintain their systems and to defend against external threats. Economic power resided

\footnotetext{
${ }^{3}$ There is little extant literature on the impact of military expenditures on labor force changes to guide our work. Angrist (1998) finds that soldiers received higher pay than comparable civilians in the early 1980 s and that military participation is associated with higher rates of employment after service for veterans.
} 
within cities, the centers of economic activities in these times, and where capital was accumulated by the emerging burgher class. As military technology progressed and warfare became more expensive, these political organizations were forced to look to cities for the financing of their military activities. The resulting relationship between state and city, of coercive and economic power, solidified over this 800 year period, giving rise to the modern nation-state system.

If the historical role of the military described above seems straight forward, this is no longer the case. The coalescence of military and economic power has clearly intensified over the last two hundred years. In scholarly circles sociologists adopting global perspectives have been particularly likely to address the mutually reinforcing roles of military and economic dynamics and the states that wed them (see e.g., Frank 1969; Wallerstein 1974; Chase-Dunn 1998). In parallel fashion, President Eisenhower himself, in his farewell address (1961) to the nation treated the rise of this "new" military institution saying:

"In the councils of government, we must guard against the acquisition of unwarranted influence, whether sought or unsought, by the military industrial complex. The potential for the disastrous rise of misplaced power exists and will persist. We must never let the weight of this combination endanger our liberties or democratic processes. We should take nothing for granted. Only an alert and knowledgeable citizenry can compel the proper meshing of the huge industrial and military machinery of defense with our peaceful methods and goals, so that security and liberty may prosper together."

Eisenhower's musings aligned with C. Wright Mills' (1956) earlier description of the power elite of America. A decade before Eisenhower's speech, Mills (1956:215) warned of a great structural shift in America toward a permanent war economy with institutionalized militarism, as "military men and policies have increasingly penetrated the corporate economy."

These configurations undoubtedly have changed with the advent of new forms of military bureaucracy and electronic warfare, which depends more heavily on outsourcing and privatization - what some refer to as a "neoliberal" era. And among other things, they have been altered worldwide by transitions in global formations that only partially resemble those in force during the Eisenhower era.

\section{The Determinants of Military Expenditures}

The funding for this "new" military establishment reflects the increasing integration of this institution with private enterprise. A review of the literature suggests that military budgets are not exclusively, or even primarily, a function of external threats. In a study of eight East Asian countries between 1983 and 1993, Li (1997) finds that defense budgets were not driven by either internal or external security threats. Instead, Li finds that subsidized military industries and military corruption are the prime determinants of these expenditures. Similarly, Seiglie (1996) and Seiglie and Liu (2002) report that only a portion of military expenditures in developing countries can be accounted for by external threats and that a significant portion of these budgets are predicted by other factors.

This integration of the military and private economic spheres of the economy complicates the budget process. This is exacerbated by the emergence of "revolving elites" discussed by Mills 
(1956), a group of individuals who move from a position of power in one sphere (military, government, corporate) to another. Military and/or political decision makers may be influenced by the possibility of obtaining employment in the private sector at a later point in time. Furthermore, corporate elites who become political elites may also influence expenditures because of previous business relationships and the possibility of a subsequent return to the private sector.

\section{Military as a Modernizing Institution}

Guns and butter advocates contend that the military institution may generate modernizing and prodevelopmental results (Pye 1962; Janowitz 1964; Weede 1983, 1986, 1993; Davis, Kick and Kiefer 1989; Bullock and Firebaugh 1990; Kick et al. 1998). Modernists argue that especially in Third World countries militaries are leading social institutions that serve a vital role in producing modernized attitudes and cultivating the foreign investment and aid necessary for economic growth (Pye 1962; Stockwell and Laidlow 1981). When militaries in the developing world model their countries after successful market economics they serve integrative functions by inducing values of discipline, achievement motivation and pride in national citizenship (Andreski 1968). These are the major forces behind modernized societal development more generally (Pye 1962; Benoit 1973; Stockwell and Laidlow 1981). This argumentation directly parallels Weber's (1921) interpretations that modern military forces break down old, rigid and traditional value systems while building the individual and group discipline and rationalized approaches that promote economic growth (see also Benoit 1973, p. 88).

Benoit maintains that the military introduces both military personnel and the civilian population to:

Important industrial and urban skills and attitudes such as: following and transmitting precise instructions; living and working by the clock; noticing and reading signs; spending and saving money; using transportation (bicycles, motorcycles, autos, buses, boats, planes, etc.); working with, repairing and maintaining machinery; listening to radios; becoming interested in national and even international news; etc. (Benoit 1973:17).

Similarly, the modernized military are more open to an increasingly global "universalism" (Meyer et al. 1997) that binds conflicting national communities (tribes, ethnicities) through the recruitment of officer corps and rank-and-file military personnel from all sectors of society.

The military also is argued to contribute to economic growth across societies through its provision of housing, clothing, food, education, training, medical care and income in a manner which would not otherwise be possible. Military training relatedly fosters human capital as it heightens basic literacy and numeracy, as well as general and technical education levels. These create more rationalized and efficient means of

organization and production, inducing economic growth (Inkeles and Smith 1974; Weede 1983, 1986, 1993). With these functions the military becomes a key national institution, channeling large segments of the population into civilian sectors across the spectrum of nations (Pye 1962; 
Janowitz 1964; Johnson 1964; Russett 1969; Benoit 1973; Weede 1983; Kick and Sharda 1986; Davis et al. 1989; Kick et al. 1998).

Proponents maintain as well that militaries require national infrastructures that have widespread benefits (Benoit 1973; Sen 1984). Military transportation and communication requirements simultaneously facilitate the national infrastructure, heightening "moral density" and thereby contributing to economic growth (see Delacroix and Ragin 1981; Durkheim [1893]1984). Further, military personnel impact national growth when they participate in civic programs and agricultural production. This they have periodically done in infrastructural programs in Latin America (the construction of roads, bridges, schools and health facilities - see Agüero 1994; Bustamante 1998) as well as the U.S. and Western Europe (Samuelson 1979; Looney 1990:41). Parallel dynamics are visible in the developing countries of Africa, Asia and the Middle East (see e.g., Hestman 1978; Newman 1978; Kurian 1982; Looney 1990; Sanday 1991). Cheung (1988) identifies comparable contributions in China, where the PLA has been responsible for developing communication lines, training 1.5 million technicians, and bringing internal integration to the Xinjian region. The military's "opening-up" of otherwise inaccessible hinterland areas also is said to foster economic expansion and labor force opportunities, especially in developing societies (Newman 1978; Kurian 1982; Babin 1990; Looney 1990; Bunbongkarn 1991; Chowdhury 1991; Sanday 1991; Firebaugh 1992; Knight, Loayza, and Villanueva 1996; Kick et al. 1998).

Despite some key differences in argumentation, similar predictions are made by defense economists who identify favorable effects of the military on economic growth. These economists theorize that the military can enhance state security and enforce the property rights and market dynamics that produce growth in a global capitalist system. Military expenditures also can stimulate growth through increasing public demand and capacity utilization based on a Keynesian-style demand and related spin-offs (Baran and Sweezy 1968; Kidron 1970; Benoit 1973; Bluestone and Havens 1986). Military research and defense expenditures may also yield technological innovations with broader applicability that can enhance more widespread production and growth.

As a modernizing institution, the military can create socioeconomic conditions that fuel economic growth in both developing and developed countries. This is true insofar as the military addresses idle capacity, unemployment and underconsumption resulting from low domestic demand, while increasing profits and related investments, leading to "multiplier effects" and longer-run growth (Benoit 1973; Deger 1986; Chowdhury 1991). Payoffs for already developed countries such as the U.S. can be greater during slack economic periods and as a result of a mounting convergence between military and civilian technologies. While there always has been at least some overlap between useful technical innovations in the military and market economies of advanced societies, the emergence of information and network-centric technologies in both sectors suggest that synergies, rather than "trade-offs" may increasingly typify military-market relationships. To be sure, this is relevant to national economic growth as well as the institutionalizing of the "permanent war economy" (Eisenhower 1961; Mills 1956).

In sum, modernization theorists in sociology and a number of defense economists share the view that in many ways the military bolsters national economies. The causal mechanisms they focus upon differ in a number of ways, but regardless of pathway they come to comparable conclusions about favorable military inputs to national economic well-being. However, whether the arguments are cast at more abstract or concrete levels, political economy approaches reach an 
BRINGING THE MILITARY BACK IN 148

opposing conclusion. In concert with a different clustering of defense economists, they conclude that "guns or butter" more aptly describes the impact of the military on the national economy.

\section{The Political Economy of Military Expenditures}

In sharp contrast to the "guns and butter" interpretation, political economy and dependency theorists contend that militarization negatively impacts national socioeconomic processes, including economic growth (see Kaldor 1976; Eide 1976; Albrecht 1977; Lock and Wulf 1977; Senghaas 1977; Wolpin 1977; Abell 1994; Levy 1998). Poorer countries have relied heavily on foreign, particularly U.S., political-military support in return for domestic investment concessions. These arrangements contribute to a variety of economic and social ills, including economic stagnation (Senghaas 1977; McKinlay and Mughan 1984:251-258; Trumper and Phillips 1997). For example, insofar as the military in developing countries depends upon foreign patrons such as the U.S., domestic economic policies favor patron capital accumulation requirements rather than domestic needs.

The military also may not bring about the social integration emphasized by modernists. Military culture and national culture need not be mutually supportive and can in fact be disarticulated due to the patron-conditioned functions that third-world militaries perform. Further, recruitment into the military may be restricted to groups and communities that are already comparatively privileged and powerful. A number of dependency economists level even more serious indictments of military expenditures as a retardant to economic growth. It is argued that when military participation is relatively low, its role in training citizens for the economy is marginal. Further, unless military and economic institutions are well articulated, military training can be largely irrelevant to the rest of the economy. These theorists thus emphasize "guns or butter" as a crucial economic growth alternative.

A number of defense economists also argue for unfavorable effects of the military on economic growth, although from a vantage. Their contentions extend broadly to both poorer and richer nations. Some defense economists claim when labor is in short supply and skilled workers are at a premium, military employment of skilled labor becomes an "opportunity cost" for the rest of the domestic economy. Put another way, if the military and productive civilian sectors of a society are in competition rather than a synergy, the military will be a human capital drain rather than an overall economic stimulant for both wealthy and poorer nations (Russett 1979; Samuelson 1979; Knight et al. 1996).

Comparable arguments apply to military expenditures generally. Samuelson (1979) questions reliance upon a "permanent war economy," arguing that similar attention to civilian alternatives would yield equivalent employment and income multiplier effects, as well as more favorable, long-term positive impacts (Abell 1994). While the education and skills military personnel receive can benefit both the individual and society, these benefits may not be optimal as "spillovers"-instead, specific training in other skill-related areas probably produces greater payoffs to economic growth (Russett 1979).

Writers for the International Monetary Fund (Knight et al. 1996:1) claim that, in general, military spending may reduce resources available for investment in "productive capital, education, and market-oriented technological innovation." Thus, military expenditures may adversely impact investments, savings and human capital, and infrastructure programs, which could make far greater contributions to economic growth through their inputs to other 
components of the economy (Mintz and Chan 1991; Mintz and Huang 1991; Ward and Davis 1992; Frederiksen and Looney 1994; Heo and DeRouen 1998). More concretely, increased military spending must be paid for by increased taxations, and it usually results in budget deficits which reduce savings, consumption and returns on fixed capital. Since military spending is not governed by more efficient "market processes" it creates "relative price distortions," "deadweight losses to total productive capacity," and non-competitive rent-seeking activities (Knight et al 1996). These circumstances are aggravated insofar as military technologies are disarticulated from the technologies that are most relevant to the market and to consequent economic growth. These arguments align with political economy interpretations in advancing "guns or butter" interpretations.

\section{Military Expenditures, Labor Force Growth, and Economic Development}

It is theorized that military expenditures expand the labor force. Griffin, Devine, and Wallace (1982) argue, from a new-Marxian perspective, that expenditures are used by national policy makers to regulate levels of unemployment during periods of economic contraction. Their empirical findings of the effects of aggregate military expenditures on labor force growth between 1949 and 1976 support their argument. These findings are replicated by Mintz and Hicks (1984).

It is argued further that labor force expansion should have a positive effect on economic growth. Crenshaw, Ansari, and Christenson (1977) outline several reasons for this relationship. First, labor force growth boosts aggregate demand (Bloom and Freeman 1988, Barlow 1994), In addition, there are economies of scale due to expansion of the domestic market, reductions in the cost of the public infrastructure, and a greater complexity in the division of labor (Todaro 1989).

Combining these two arguments, we might reasonably expect military expenditures to increase economic development by expanding the labor force. It is this pathway we intend to examine.

\section{Empirics of Military Spending and Growth}

Unfortunately, the empirical literature offers divided assessments of military-economic growth interdependencies. Benoit's (1973) landmark cross-national study shows that defense spending may stimulate aggregate demand leading to economic growth, although his effort has been critically evaluated in subsequent research (Ball 1983). Others report favorable defense spending effects (Kennedy 1974; Whynes 1979), especially over the longer term (Babin 1990), in resourcerich lesser developed countries (Fredericksen and Looney 1982) or in service-related sectors only (Hall 1988). Contrasting results show no consistent defense spending effects (Chowdhury 1991), inconclusive findings (Biswas and Ram 1986) or negative effects for industrialized countries (Smith 1977).

There are a variety of plausible reasons for these divided assessments. One is the unit of analysis; whether these processes are examined for individual states (Mintz and Hicks 1984; Mintz and Huang 1991; Ward and Davis 1992; Frederiksen and Looney 1994), or geographic regions such as Asia (Heo and DeRouen 1998), Latin America (Looney and Frederiksen 1986), or Africa (Looney 1988). 
Another concerns the lack of model specificity. For instance, Mintz and Huang (1991; Deger 1986) argue that it is important to consider the intervening mechanisms by which military expenditures impact economic development.

Also, expenditures may effect economic growth differently, hinging on differences in national characteristics. For example, Frederiksen and Looney (1982, Looney 1988) find that expenditures as a whole spur economic growth for developing countries that are not "resource constrained" (i.e. debt, access to credit) but hinder growth for those that are. Mintz and Stevenson (1995) suggest that expenditures may have a positive effect for a small group of wealthier countries, such as Israel, Taiwan, Iran, and Iraq, but this positive effect may not be true for poorer countries.

We address these concerns in our subsequent analyses. We analyze a cross-national sample, reducing bias in generalizations which is more likely in analysis of single countries or regions. We further statistically adjust for the effects of national characteristics, providing better estimates of real military expenditure - economic growth linkages (e.g., labor force). And we focus on what we feel is a particularly important factor in military expenditure effects - the disaggregation by type of military expenditures.

\section{Disaggregating Military Expenditures: A Capital Intensive Military}

There are many critiques of prior research. For instance, Griffen, Devine and Wallace (1982a, 1982b; see also Mintz and Hicks 1984; Kick and Sharda 1986) argue that when total military expenditures effects only are estimated, the different effects of its parts are missed. This position finds empirical support in the literature. For instance, prior results, while somewhat inconsistent, show that military expenditures in total may not foster economic advance, money spent on soldiers ("military participation") specifically serves a "modernizing function" (Kick and Sharda 1986; Babin 1990; Bullock and Firebaugh 1990; Weede 1993; Kentor 1998; Kick, Davis, and Kentor 2006). Findings such as these justify separating military expenditures into those supporting military personnel versus those for military equipment (although we note that. institutions such as secondary education may promote human capital growth even better than military participation) (Kentor 1998; Kick et al 1998; Kick et al. 2006).

In this study, we examine a new aspect of military expenditures-military expenditures per soldier. This measure, introduced by Kentor (2004), reflects the level of capital intensiveness of the military. Capital intensiveness taps the quality, or structure, of this form of military expenditures in a way that total military expenditures cannot. The capital-intensiveness of the military is very important to a world undergoing significant changes in military equipment and personnel. For example, modern warfare depends more on electronics, communication, and information technology than it has before. Artificial intelligence, robotic planes and other unmanned vehicles, imaging sensors, and wireless communications increasingly define modern warfare. Consistent with these changes are transformations in personnel themselves. Mobile armed forces now are trained in operating highly technical and complex systems. The parallel need for greater and greater coordination results in more emphasis on key functions performed by bureaucrats, specifically officers, than in the past.

We suggest this new focus of military spending inhibits economic growth, in part, by limiting the military's traditional role as "employer of last resort" and "pathway of upward mobility." "Hi-tech" armies need highly trained soldiers to use the more sophisticated weaponry. 
This requires, first, a higher level of intelligence and education for many inductees than was previously needed. This excludes some of those who in earlier times used the military as an employer of last resort. Second, a capital intensive military requires significantly increased training costs and a larger bureaucratic apparatus. The more restrictive recruitment policies associated with growing bureaucracies and high technology capabilities places relatively higher limits on the number of uneducated (undereducated) and unemployed (underemployed) people. This prospective labor pool might otherwise use skills acquired in the military to obtain jobs in the private sector. The dynamics of the new military thus restrict the labor pool and increase private sector training costs. Long-term, a more selective military may perpetuate an "underclass" that can no longer avail itself of the upward mobility previously afforded by the military. We conjecture too that this may increase social welfare costs and exacerbate income inequality. Finally, a more limited military focused on high-technology warfare can be disarticulated in social and economic ways from the broader societal needs it once served. It is not uncommon among more agrarian societies with labor-intensive militaries to find soldiers assisting farmers and the construction of basic infrastructures such as roadways and bridges. The "new hi-tech military" will be less likely to provide the socially integrative and infrastructural functions discussed by modernists and others (e.g., Andreski 1968).

Following the above arguments, we derive our primary research hypothesis: Military expenditures per soldier will inhibit economic growth by slowing the growth in the labor sector. It is the empirical testing of this hypothesis to which we now turn, alongside our examination of other military impacts on economic growth.

\section{EMPIRICAL ANALYSES}

We examine cross-national linkages between economic growth and "decomposed" military antecedents to growth for a wide range of countries. We introduce appropriate statistical controls from prior efforts, but also controls and technical adjustments that have not been employed in most prior studies, while treating a contemporary but essentially unanalyzed time period, 1990 to 2003. This relatively unique analytical undertaking thus focuses upon the post Cold War period, including a time when the global "peace dividend" was in operation. Another important aspect of these forthcoming analyses is that the period examined is one of the first treated in the literature in which information technology has played a central role in weapons production and military engagements around the world.

\section{Methodology}

In the first part of the analyses, we use panel regression models to estimate the impacts of various aspects of military on economic growth. ${ }^{4}$ In this research design, the dependent variable,

\footnotetext{
${ }^{4}$ Many scholars (Frees 2004; Halaby 2004; Wooldridge 2006) argue that fixed and random effects models are preferable to the panel models used here due to heterogeneity bias. We agree. However, FEM/REM models require multiple time periods for analysis. This would be inappropriate for this study, since we are arguing that the time period under question (1990-2003)
} 
measured as a change score $((2003-1900)$ / 1990) is regressed on the independent variables at Time 1 (1990). We also include a measure of the dependent variable at Time 1 as an independent variable. This "lagged" dependent variable is included to control for prior states of the countries examined and the possibility of reciprocal causality. ${ }^{5}$ The resulting parameters estimate the effect of the independent variables in 1990 on the change in the dependent variable over the time period in question. In the second phase of the analyses, we use structural equation models to estimate the direct and indirect effects of the exogenous military variables on labor force growth and economic development.

\section{Countries Included in the Analyses}

Researchers have chosen various ways to define the appropriate population for cross-national analyses on economic growth. Some choose to exclude wealthy countries from their analyses, arguing that the processes that affect less developed countries differ from those for developed nations (Chase-Dunn 1998; Kentor 1998, 2000, 2001; Kentor and Boswell 2003). The sample is typically determined by national scores on measures such as the GDP per capita. Others include all countries for which data are available, due to an otherwise very limited case base, or argue that there is insufficient theory to warrant a separate sample. We estimate our model for two samples. The first sample includes all countries for which complete data are available $(\mathrm{N}=67)$. The second sample excludes countries with GDP per capita of $\$ 15,000$ or greater. This excludes developed countries such as the United States, France, and Germany $(\mathrm{N}=50)$. This dual sample methodology allows us to examine the sensitivity of the results to sample selection. A list of countries included is provided in Appendix A. ${ }^{6}$

\section{Variables Included in the Analyses ${ }^{7}$}

Three aspects of military expenditures are included as independent variables. The primary variable of interest is Military Expenditures per Soldier 1990 (MEPS), which was discussed above in some detail. This is calculated by dividing total military expenditures by the number of military personnel. ${ }^{8}$ These data are taken from Kentor (2004). This measure is an indicator of the level of

is a unique period due to widespread adoption of hi-technology military technology during this time.

${ }^{5}$ The lagged dependent variable may be highly correlated with the dependent variable, resulting in an artificially high $\mathrm{R}^{2}$. It also reduces the size of the standardized coefficients of the other independent variables. For this reason, we have chosen to use a change score measure of the dependent variable, which more accurately reflects the magnitudes of the betas.

${ }^{6}$ A lack of data results in the exclusion of some notable countries, such as China. This is an unfortunate, but unavoidable, aspect of cross-national research.

${ }^{7}$ In analyses not presented, we included the military personnel ratio (military personnel/total population), which Kick, Davis, and Kentor (2005) find has a negative effect on income inequality. It had no significant impact on our findings.

${ }^{8}$ While we intend this variable to measure expenditures on costly hi-tech equipment, it will also include items such as uniforms and other "low tech" materials. However, the vast majority of these expenditures will be for technologically sophisticated goods (SIPRI 2004). 
capital intensiveness of the military. ${ }^{9}$ This variable is highly correlated with another independent variable, GDP per capita. The bivariate correlation is .84 in the "all country" sample, raising the issue of multicollinearity as reflected in unacceptably high VIFs It is therefore necessary to use a residualized measure of MEPS by regressing MEPS on GDP per capita and using the residuals for this sample. The resulting variable reflects that aspect of MEPS not accounted for by GDP per capita. Fortunately, the bivariate correlation is somewhat lower for the less developed country sample (.63), and so the model can be estimated without residualizing MEPS.

Therefore, we estimate models for the LDC sample with both the residualized and nonresidualized form of MEPS. The second variable is total Military Expenditures/GDP 1990, taken from the World Bank (1998). These data are logged (Ln) to reduce the skewness of the distribution. The third aspect is Arms Imports as a percentage of total imports, also obtained from the World Bank (1998) and logged. This is a potentially significant variable, as it could be argued that purchases of foreign goods will not generate the same "spin-off" effects as purchases of domestic equipment.

Several theoretically significant control variables measured in 1990 are included in the analyses. Gross Domestic Product (logged) is included to control for the overall size of the economy. The argument is that the impact of the military establishment will have a lesser impact on relatively larger economies. Secondary School Enrollments is included as a measure of human capital. There should be less of a need for the military to be "employer of last resort" in countries with a relatively highly educated population that is more likely to be employable in the private sector. This variable is residualized due to its high correlation with GDP per capita. Gross Domestic Investments/GDP is included to control for its positive effect on the domestic economy. These data are taken from the World Bank (1998). Also included is a dummy variable for Africa (coded 1 for African country, 0 for others), to control for specific geographic effects (Lenski and Nolan 1984). Finally, we include per capita GDP in 1990 (logged) as the lagged dependent variable. ${ }^{10}$ Correlations and descriptive statistics for all variables are given in Appendices B1 $(\mathrm{N}=67)$ and $\mathrm{B} 2(\mathrm{~N}=50)$.

\section{RESULTS $^{1112}$}

Several key findings emerge from our analyses. Foremost among these is that military expenditures per soldier in 1990 inhibit growth of per capita GDP between 1990 and 2003, net of

\footnotetext{
${ }^{9}$ It is worth emphasizing that this variable is expenditures PER soldier, and does not reflect expenditures $O N$ a soldier.

${ }^{10}$ In analyses not shown, two other control variables were included, military personnel / population and foreign direct investment flows. Neither variable was statistically significant in its effects, nor did their inclusions alter the other parameters.

${ }^{11}$ Variance inflation factors (VIFs) were examined for possible multicollinearity problems. None were found. Cook's D statistics were all within normal ranges, indicating no influential cases.

${ }^{12}$ In results not shown, models were estimated with level scores of the dependent variables. No substantive differences were found.
} 
Table 1: Unstandardized Coefficients from the Regression of GDP per capita Growth 1990-2003 on Military Expenditures per Soldier and Other Independent Variables in 1990:

All Countries (Model 1) and Less Developed Countries Only (Models 2 and 3)

\section{Independent Variables 1990 \\ GDP per capita}

Gross Domestic Product

Gross Domestic Investment

Africa

Secondary Education Enrollments

Total Military Expenditures/GDP (residualized)

Total Military Expenditures/GDP (Ln)

Arms Imports

Military Expenditures per Soldier (residualized)

Military Expenditures per Soldier (Ln)

Constant

Adjusted $\mathrm{R}^{2}$

Cases

Model 1
-.026
-.169
$(.032)$
.014
.113
$(.024)$

$.012 *$

.406

$(.004)$

$-.121$

$-.219$

$(.084)$

$.005^{*}$

.263

$(.002)$

.007

.021

$(.052)$

.170

67

$\begin{array}{ll}\text { Model 2 } & \text { Model 3 } \\ -.028 & .042 \\ -.121 & .178 \\ (.043) & (.047) \\ .015 & .014 \\ .095 & .084 \\ (.029) & (.029) \\ .015^{* *} & .015^{* *} \\ .537 & .545 \\ (.004) & (.004) \\ . .100 & -.102 \\ -.182 & -.186 \\ (.091) & (.091) \\ .004^{*} & .004 * \\ .249 & .239 \\ (.002) & (.002) \\ .002 & \\ .007 & \\ (.063) & \\ & -.003 \\ & -.008 \\ & (.063) \\ .032 & .034 \\ .260 & .277 \\ . .022) & (.022) \\ -.102^{*} & \\ -.292 & \\ (.054) & \\ & -.089 * \\ & -.327 \\ .048 & .052) \\ .256 & .246 \\ 50 & 50 \\ & \\ & \\ & \\ & \\ & \\ & \\ & \end{array}$

Note: ${ }^{*} \mathrm{p}<.05$ (one-tailed tests), ${ }^{* *} \mathrm{p}<.01$ (one-tailed tests); Standardized coefficients appear in brackets, standard errors in parentheses.

control variables. ${ }^{13}$ It does so, at least in part, by slowing the growth of the national labor force, which in turn retards economic growth. This process is most pronounced in the least developed countries. The second key finding is that arms imports appear to stimulate the growth of the labor

\footnotetext{
${ }^{13}$ Inspection of a scatterplot of MEPS in 1990 and GDP per capita 2003, given in Appendix C, indicates a negative bivariate relationship with no obvious outliers.
} 
force in less developed countries, but has no significant impact on the labor force in the larger sample.

The initial findings are detailed in Table 1. Three models are presented. In Model 1 we include all countries for which data are available $(\mathrm{N}=67)$, while Models 2 and 3 excludes developed countries $(\mathrm{N}=50)$. In these analyses, per capita GDP growth 1990 to 2003 is regressed on the three military measures, along with the controls of GDP, GDP per capita, gross domestic investment, secondary education, the AFRICA dummy variable, and per capita GDP in 1990 (the lagged dependent variable). As noted above, only one military measure, military expenditures per soldier, has a significant (negative) effect on GDP per capita growth. Neither total military expenditures nor arms imports have a systematic effect on economic growth. As expected from the literature, control variables of gross domestic and secondary education enrollments have positive effects on the dependent variable. Finally, the dummy variable for Africa does not have a significant negative effect.

The findings for the reduced sample (models 2 and 3) mirror those for the full sample described above. Model 2 includes the residualized form of MEPS and Model 3 uses the nontransformed variable. In both cases, military expenditures per soldier in 1990 has a significant negative effect on GDP per capita growth between 1990 and 2003, net of other independent variables in the model. Neither of the other two aspects of military expenditures, total military expenditures/GDP or arms imports, have a significant impact on economic growth. Gross domestic investment and secondary education have significant positive effects, while the Africa dummy variable is not significant.

A comparison of the effects of military expenditures per soldier across the three models is instructive. ${ }^{14}$ First, the consistency of the effects indicates that the finding is not an artifact of the countries included in the analyses, or whether or not MEPS is residualized. Second, the impact of MEPS on GDP per capita growth is greater in less developed countries than in developed countries. The unstandardized coefficient for MEPS in model 2 is nearly $25 \%$ greater than that for MEPS in model 1. Moreover, The beta for MEPS in Model 1 (-.168) is the weakest of the three significant variables (the others being gross domestic investment and secondary educational enrollments), while in Models 2 and 3, the relative impact of MEPS is greater than that of educational attainment.

In the second set of analyses, we test our hypothesis that military expenditures per soldier retards growth of the labor force during this time period. In these panel regression models, (see Table 2), the labor force as a percentage of the total population 1990 to 2003 is regressed on military expenditures per soldier and other independent variables, including the lagged dependent variable, in 1990. Two key findings emerge. First, military expenditures per soldier significantly slow the growth of the labor force, using either the residualized or non-residualized forms of MEPS. Again, the effects appear to be greater in less developed countries. The unstandardized effect of MEPS in Model 2 is nearly 20\% greater than in Model 1, and the relative (standardized) effects are also larger. Second, arms imports have a significant positive effect on labor growth over this period, but only for the LDC sample. It is worth noting that for less developed countries

${ }^{14}$ An alternative method for comparing effects within sample subgroups involves inclusion of an interaction term in which the independent variable is multiplied by a dummy variable for each subgroup. This is referred as a "slope dummy" (Kick et al. 1998). In analyses not shown, the results of the slope dummy analyses were consistent with the split sample findings given above. 
the relative magnitudes of MEPS and arms imports are nearly identical, though opposite. Total military expenditures have no consistent effect. Two control variables, gross domestic product and gross domestic investment, have significant positive impacts on labor force growth over this period.

Table 2: Unstandardized Coefficients from the Regression of Labor Force/Pop Growth 1990-2003 on Military Expenditures per Soldier and Other Independent Variables in 1990:

All Countries (Model 1) and Less Developed Countries Only (Models 2 and 3)

\begin{tabular}{|c|c|c|c|}
\hline Independent Variables 1990 & Model 1 & Model 2 & Model 3 \\
\hline \multirow[t]{3}{*}{ Labor Force/Pop 1990} & $-.808 * *$ & $-.766 * *$ & $-.771 * *$ \\
\hline & -.745 & -.660 & -.664 \\
\hline & $(.087)$ & $(.108)$ & $(.108)$ \\
\hline \multirow[t]{3}{*}{ GDP per capita } & -.008 & -.004 & -.009 \\
\hline & -.184 & -.069 & .151 \\
\hline & $(.006)$ & $(.008)$ & $(.009)$ \\
\hline \multirow[t]{3}{*}{ Gross Domestic Product } & $.010 *$ & $.009 *$ & $.009 *$ \\
\hline & .310 & .215 & .213 \\
\hline & $(.004)$ & $(.005)$ & $(.005)$ \\
\hline \multirow[t]{3}{*}{ Gross Domestic Investment } & $.002 * *$ & $.002 * *$ & $.002 * *$ \\
\hline & .243 & .313 & .320 \\
\hline & $(.001)$ & $(.001)$ & $(.001)$ \\
\hline \multirow[t]{3}{*}{ Africa } & -.011 & -.009 & -.009 \\
\hline & .074 & -.060 & -.061 \\
\hline & $(.015)$ & $(.017)$ & $(.017)$ \\
\hline \multirow[t]{3}{*}{ Secondary Education Enrollments } & .000 & .001 & .001 \\
\hline & .076 & .142 & .134 \\
\hline & $(.000)$ & $(.000)$ & $(.000)$ \\
\hline \multirow[t]{3}{*}{ Total Military Expenditures/GDP } & -.004 & -.010 & -.010 \\
\hline & -.042 & -.104 & -.106 \\
\hline & $(.010)$ & $(.012)$ & $(.012)$ \\
\hline \multirow[t]{3}{*}{ Arms Imports } & .004 & $.007 *$ & $.007 *$ \\
\hline & .133 & .219 & .226 \\
\hline & $(.003)$ & $(.004)$ & $(.004)$ \\
\hline \multirow[t]{3}{*}{ Military Expenditures per Soldier (residualized) } & $-.016^{*}$ & $-.019 *$ & \\
\hline & -.168 & -.207 & \\
\hline & $(.009)$ & $(.004)$ & \\
\hline \multirow[t]{3}{*}{ Military Expenditures per Soldier (Ln) } & & & $-.081 *$ \\
\hline & & & -.251 \\
\hline & & & $(.009)$ \\
\hline Constant & $.338 *$ & $.306 * *$ & $317 * *$ \\
\hline Adjusted $\mathrm{R}^{2}$ & .622 & .626 & .626 \\
\hline Cases & 67 & 50 & 50 \\
\hline
\end{tabular}

Note: ${ }^{*} \mathrm{p}<.05$ (one-tailed tests), ${ }^{* *} \mathrm{p}<.01$ (one-tailed tests); Standardized coefficients appear in brackets, standard errors in parentheses. 


\section{Causal Models}

As discussed earlier, we theorize that MEPS inhibits economic growth, at least in part, by slowing the growth of the labor force. A causal model was developed to estimate this hypothesis. In this model, military expenditures per soldier, arms imports, total military expenditures, and control variables in 1990 are exogenous predictors of labor force growth 1990 - 2003 and GDP per capita 2003 (Ln). ${ }^{15}$ Both full and reduced sample models were estimated with AMOS software. All exogenous variables were permitted to covary, as were the error terms for the endogenous variables. The primary path coefficients are presented for the full and reduced samples in Figures 1 and 2, respectively. Complete results for both models are given in Appendices D and E.

The primary finding in these analyses is that the apparent negative effect of MEPS on economic growth found in the panel regression models above is actually an indirect effect mediated by the negative effect of MEPS on Labor Force Growth. A second important finding is that Arms Imports has an indirect positive effect on GDP per capita, via a direct positive effect on Labor Force Growth.

The results of these structural equation models are similar for both samples. The findings for the theoretically significant variables for the two samples are presented in Figures 1 and 1B, and the maximum likelihood estimates for all variables are given in Appendices $\mathrm{D}(\mathrm{N}=67)$ and $\mathrm{E}$ $(\mathrm{N}=50)$.

Military expenditures per soldier in 1990 slows Labor Force Growth 1990-2003, while Arms Imports has a positive impact on labor growth. Both Gross Domestic Investment and Secondary Education Enrollments also have positive effects on labor growth. In turn, Labor force growth 1990 - 2003 has a significant direct positive effect on GDP per capita in 2003.

A comparison of the unstandardized coefficients across samples indicates that the impact of MEPS and Arms Imports on Labor Force Growth is greater in the reduced sample of Less Developed Countries. The negative effect of MEPS on Labor Force Growth is more than a third larger in the reduced sample, with an unstandardized coefficient of -.022 versus -.016 for the full sample. The effect of Arms Imports on Labor Force Growth is 50\% larger in the reduced sample $(b=.006$ vs. $b=.004$ for the full sample). Finally, the impact of Labor Force Growth on GDP per capita is slightly larger in the full sample, $(b=4.486$, vs. 3.394 for the reduced sample).

\section{DISCUSSION AND CONCLUSIONS}

The goal of this research was to theoretically and empirically clarify the debate on the impact of military expenditures on economic development, which usually rests on "guns and butter" or "guns or butter" formulations and, in so doing, to "bring the military back in" to a crucial area of sociological inquiry. We did so by examining the structure, or quality, of one aspect of these expenditures rather than aggregate levels. Foremost, we find that military expenditures per

${ }^{15}$ Initially, a saturated model was estimated. A second model was then estimated that included only significant paths. 
Figure 1. Causal Models of the Effect of Military Expenditures per Soldier and Arms Imports in 1990 on Labor Force Growth 1990-2003 and GDP per capita 2003. All Countries $(\mathrm{N}=67)$ and Less Developed Countries $(\mathrm{N}=50)$.

1A. All Countries $(\mathrm{N}=67)$

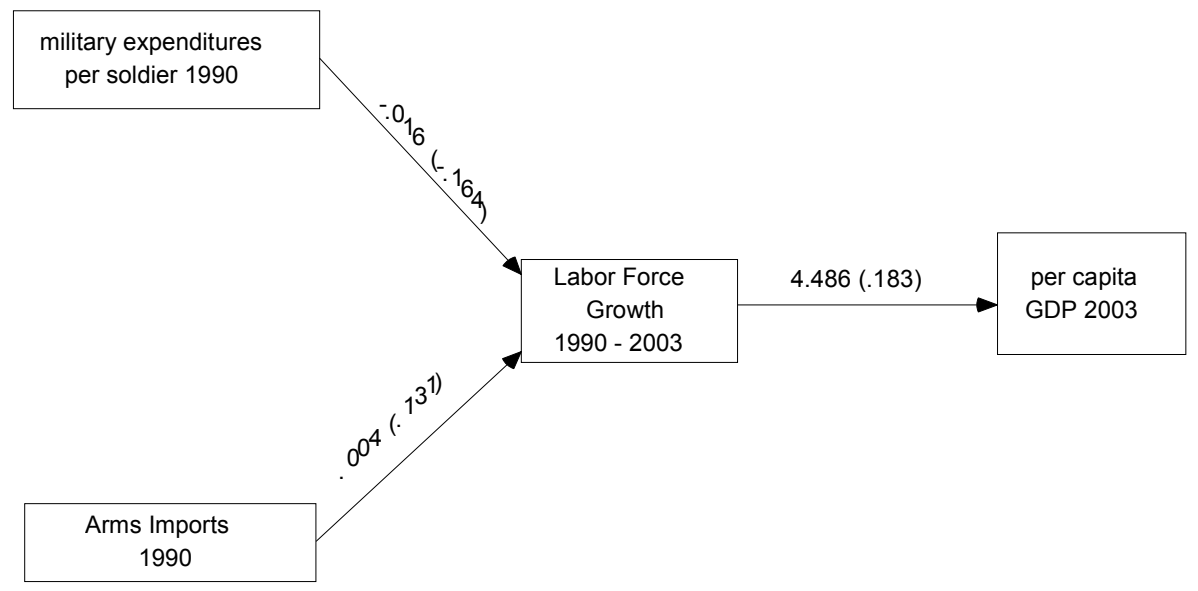

1B. Less Developed Countries Only $(\mathrm{N}=50)$

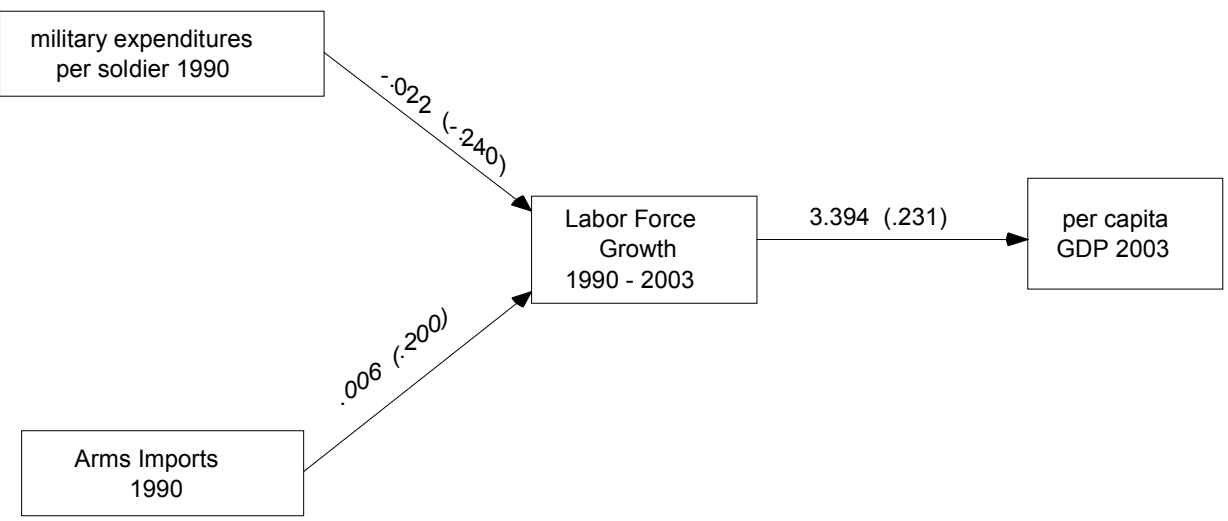

(Standardized Coefficients in parentheses) 
soldier, a measure of the capital intensiveness of the military organization, inhibits economic growth. It does so, in part, by restricting expansion of the labor force. ${ }^{16}$ We argue that a capital intensive military apparatus is less likely to facilitate upward mobility for uneducated and unemployed people than would be a more labor intensive military. The Center for Defense Information (2005) quantifies the magnitude of this "transition." They point out that the 2005 U.S. military budget will surpass spending at the height of the Vietnam War (in constant dollars), while maintaining a military one-third the size of that amassed during Vietnam, and with less than 200,000 troops in Iraq and Afghanistan.

Recent trends world-wide support our hypothesis that "marginalized" people are increasingly denied access to military training. In the United States, for example, the educational level of military inductees has risen significantly over the past 30 years. ${ }^{17}$ Recruits with high school degrees ranged from $52 \%$ to $72 \%$ of total inductees in the $1970 \mathrm{~s}$, compared to approximately $94 \%$ currently. This is due to the military's increasing need for soldiers with advanced technical skills (e.g., warrant officers). This shift in the composition of the military workforce is reflected in the dramatic decline in the ratio of enlisted soldiers to officers, the "E:O ratio," which has declined from a high of 20:1 during the Spanish-American War to a current low of 5.1:1 (Nestler 2004).

According to Richard B. Meyers, Chairman of the U.S. Joint Chiefs of Staff, this transition to an increasingly technologically-based military is likely to continue, both at home and abroad:

Global proliferation of a wide range of technology and weaponry will affect the character of future conflict... Advances in automation and information processing will allow some adversaries to locate and attack targets both overseas and in the United States... Access to advanced weapons systems and innovative delivery systems could fundamentally change warfighting and dramatically increase an adversary's ability to threaten the United States.

The challenge over the next decade will be to develop and enhance joint capabilities in a time of global war, finite resources and multiple commitments. What is required is a transformation achieved by combining technology, intellect and cultural changes across the joint community. (Myers 2004:15)

This process is occurring in less developed countries as well. A recent article in the Washington Post highlighted the "hi-tech" reorientation of the Chinese military:

${ }^{16}$ Our findings are not sensitive to sample composition. In analyses not shown, Finland, Ireland, and Israel are excluded from the analyses, in line with Snyder and Kick's ( 1979) composition of the "core" of the world economy. No substantive differences in the findings were found, although the t-values were somewhat increased.

${ }^{17}$ This trend may be changing, if temporarily, in the U.S. The U.S. military's recent difficulty in obtaining a sufficient number of inductees has necessitated and test score standards. However, there is no indication that other countries are also altering their requirements. 
A little-discussed but key facet of China's military modernization has been a reduction in personnel and an intensive effort to better train and equip the soldiers who remain, particularly those who operate high-technology weapons...forming a core of skilled commissioned and noncommissioned officers and other specialists who can make the military run in a high-tech environment may be just as important in the long run as buying sophisticated weapons. (Cody 2005:1A)

The reduced sample analysis indicates that the economies of the least developed countries are those most affected by MEPS. This may be because there are fewer alternative employment opportunities in these countries than in developed nations, due to a relatively weak economy and a lack of domestic capital stocks.

Our finding that Arms Imports has a positive effect on Labor Force Growth in less developed countries supports the orthodoxy as well as specific hypotheses of a number of defense economists. They argue that a domestic arms industry requires significant amounts of capital, which reduces the investment capital available for more economically productive opportunities than those generated by military investments (Looney 1989:152). Specifically, arms imports are a widely used functional alternative to indigenous arms productions in much of the world. Apart from a few wealthier arms producing countries such as the U.S., the emphasis on an indigenous arms industry in lieu of reliance on arms importation may lead to continuously higher levels of military expenditures to maintain employment in defense plants or to avoid technological "lag" in regional or international arms races. This strategy may open up other domestic investment and labor-related opportunities that may be more productive. This is a worthwhile avenue for further research, especially since our finding, while in alignment with conventional reasoning and findings reported in prior efforts, contrasts with the alternative results and interpretations offered by Looney (1989).

The policy implications of findings such as ours are significant. Coupled with its implication for more adverse economic outcomes, components of the new military configuration may be found to be far more broadly consequential. As a pertinent illustration, we note that in addition to economic and labor force growth recent evidence highlights links between capital intensive militaries and the environmental footprint of nations (Jorgenson 2006). Consider as well that restricting the traditional military pathway to upward mobility may foster a bourgeoning "underclass" of permanently under or unemployable people, increasing social welfare costs along with the possibility of social unrest. We suspect that this increasing marginalization will exacerbate income inequality, an important question for future research. For these reasons, it would be prudent once again for policy planners to consider the creation of alternative paths to mobility, such as government funded civilian work programs, in order to address these issues. The Center for Defense Information (2005) appears to be equally concerned:

The major escalations of the U.S. military budget in recent years, exacerbated by increases for current military operations, and compounded by a series of major tax cuts, has increased the pressure on spending for our citizens' education, health care, environmental protection, social security, and other public services. The priority for the military should not be another generation of expensive aircraft, ships, and missiles designed to combat a superpower, but rather the more 
basic equipment and skills needed to counter adversaries who have less technologically-advanced equipment, but intense commitment to their struggle.

Further, these more concrete directions for subsequent research should be complemented by deeper theoretical treatment of contemporary state-market-society linkages as they intersect with changes in the "new military." One of these areas of particular interest is the emergence of "revolving elites" alluded to earlier. Increasingly, the same individuals take turns being political, economic, and military elites. The impacts of these elite overlaps are fertile grounds for further examination. Our hope is that this sort of macro-theorization helps to drive a new wave of middle-range theory and concrete hypothesis testing on the determinants and consequences of military forms the world over. While we have focused on economic growth, it is equally (or perhaps more) important to examine other outcomes, including human/social wellbeing, income inequality, and environmental degradation, to mention only a few.

We close with a call to "bring the military back in" to the forefront of sociological inquiry. This work draws attention to the impact of the military establishment on economic development, but there are many other areas in which coercive power plays a central role. Foremost among these is the role of the military in the debate over the strength of the state vis-àvis transnational corporations discussed above. And the current Iraqi War highlights the potential policy implications of this area of study. Ignoring the military won't make it disappear.

\section{REFERENCES}

Abell, John D. 1994. "Military Spending and Income Inequality." Journal of Peace Research 31:35-43.

Agüero, Felipe. 1994. "The Latin American Military: Development, Reform, and 'NationBuilding'." In Security, Democracy, and Development in U.S. - Latin American Relations, edited by L. Schoultz, W. C. Smith and A. Varas. Coral Gables, FL: NorthSouth Center Press at the University of Miami.

Albrecht, Ulrich. 1977. "Technology and Militarization of Third World Countries in Theoretical Perspective." Bulletin of Peace Proposals 8(2):124-126.

Andreski, Stanislov. 1968. Military Organization and Society. 2d ed. Berkeley, CA: University of California Press.

Angrist, Joshua. 1998. "Estimating the Labor Impact of Voluntary Military Service Using Social Security Data on Military Applicants." Econometrica. 66(2): 249-288.

Arms Control and Disarmament Agency, (ACDA). World Military Expenditures and Arms Transfers 1999-2000. Washington D.C.: U.S. Government Printing Office.

Babin, Nehama E. 1990. "Military Expenditures and Education: Allies or Adversaries in Third World Development." Journal of Political and Military Sociology 18:267-283.

Ball, Nicole. 1983. "Defense and Development: A Critique of the Benoit Study." Economic Development and Cultural Change. 31:507-524.

Baran, Paul and Paul Sweezy, 1968. Monopoly Capital: An Essay on the American Economic and Social Order. Harmondsworth: Penguin.

Barlow, Robin. 1994. "Population Growth and Economic Growth: Some More Correlations." Population Development and Review. 20:153-165 
Benoit, Emile. 1973. Defense and Economic Growth in Developing Countries. Lexington, MA: Lexington Books.

Biswas, B. and R. Ram. 1986. "Military Expenditures and Economic Growth in Less Developed Countries: An Augmented Model and Further Evidence." Economic Development and Cultural Chang.e 34:361-372.

Bloom, David E. and Richard B. Freeman. 1988. "Economic Development and the Timing and Components of Population." Journal of Policy Modeling. 10(1): 57-81.

Bluestone, B. and J. Havens. 1986. "Reducing the Federal Deficit Fair and Square." Paper for the Symposium of the Joint Economic Committee. The American Economy in Transition: From the Second World War to the 21st Century. Washington, DC: US Congress.

Budget of the U.S. Government. 2008. Historical Tables Fiscal Year 2008. Accessed online at: $<$ http://gpoaccess.gov/usbedget/fy08/hist.html $>$

Bullock, Brad and Glenn Firebaugh. 1990. "Guns and Butter? The Effect of Militarization on Economic and Social Development in the Third World." Journal of Political and Military Sociology. 18:231-266.

Bunbongkarn, Suchit. 1991. "The Thai Military and Its Role in Society in the 1990s." Pp. 67-81 in The Military, the State, and Development in Asia and the Pacific, edited by V. Selochan. Boulder, CO: Westview.

Bustamante, Fernando. 1998. "Democracy, civilization change, and the Latin American Military." Pp. 345-370 in Fault Lines of Democracy in Post-Transition Latin America, edited by F. Agüero and J. Stark. Coral Gables, FL: North-South Center Press at the University of Miami.

Center for Defense Information. 2005. FPIF-CDI Special Report: A Unified Security Budget for the United States, 2006. <http://www.fpif.org/papers/0505usb_body.html>

Chase-Dunn, Christopher. 1998. Global Formation: Structure of the World Economy. (updated ed.). Lanham, MD: Rowan and Littlefield.

Cheung, Tai Ming. 1988. "Disarmament and Development in China: The Relationship Between National Defense and Economic Development." Asian Survey 28: 757-774.

Chowdhury, Abdur. 1991. "A Causal Analysis of Defense Spending and Economic Growth." Journal of Conflict Resolution. 35:80-97.

Cody, Edward. 2005. "China Builds a Smaller, Stronger Military; Modernization Could Alter Regional Balance of Power, Raising Stakes for U.S." Washington Post, April 12, 2005.

Crenshaw, Edward M., Ansari Z. Ameen and Matthew Christenson. 1997. "Population Dynamics and Economic Development: Age-Specific Population Growth Rates and Economic Growth in Developing Countries, 1965-1990." American Sociological Review. 62(6):974984.

Davis, Byron L., Edward L. Kick, and David Kiefer. 1989. "The World-System, Militarization, and National Development." Pp. 27-45 in World in the World-System, edited by R. K. Schaeffer. New York: Greenwood.

Deger, Saadet. 1986. Military Expenditure in Third World Countries. London: Routledge and Kegan Paul.

Delacroix, Jacques and Charles Ragin. 1981. "Structural Blockage: A Cross-National Study of Economic Dependency, State Efficacy, and Underdevelopment." American Journal of Sociology. 86:1311-1347.

Durkheim, Emile. [1893] 1984. The Division of Labor in Society. New York: Free Press. 
Eide, Asbjorn. 1976. “Arms Transfer and Third World Militarization." Bulletin of Peace Proposals 8:99-102.

Eisenhower, Dwight David. 1961. Farewell Address, delivered January 17.

Firebaugh, Glenn. 1992. "Political Instability and Economic Growth: Evidence From SubSaharan Africa." Economic Development and Cultural Change 40:829-841.

Firebaugh, Glenn and F. D. Beck. 1994. "Does Economic Growth Benefit the Masses? Growth, Dependence, and Welfare in the Third World." American Sociological Review 59:631653.

Frank, Andre Gunder. 1969. Capitalism and Underdevelopment in Latin America. New York: Monthly Review Press.

Fredericksen, P.C. and R. E. Looney. 1982. "Defense Expenditures and Economic Growth in Developing Countries: Some Further Empirical Evidence." Journal of Economic Development 7:113-124.

. 1994. "Budgetary Consequences of Defense Expenditures in Pakistan: Short-Run Impacts and Long-Run Adjustments." Journal of Peace Research 31: 11-18.

Frees, Edward W. 2004. Longitudinal and Panel Data. Cambridge: University of Cambridge Press.

Griffin, Larry, Joel Devine, and Michael Wallace. 1982. "The Political Economy of Military Spending: Evidence form the U.S." Cambridge Journal of Political Science 6: 1-14.

Halaby, Charles N. 2004. "Panel Models in Sociological Research: Theory into Practice." Annual Review of Sociology 30:507-544.

Hall, R. E. 1988. "The Relation between Price and Marginal Cost in U.S. Industry." The Journal of Political Economy 96(5):921-947.

Heo, Uk and Karl DeRouen. 1998. "Military Expenditures, Technological Changes, and Economic Growth in the East Asian NICs." The Journal of Politics 60: 830-846.

Hestman, H. R. 1978. "The Potential Role of the Military in National Development," in Militaria (Milan).

Inkeles, Alex and David Smith. 1974. Becoming Modern: Individual Change in Six Developing Countries. Cambridge, Mass: Harvard University Press.

Janowitz, Morris. 1964. The Military in the Political Development of New Nations. Chicago: University Press.

Jenkins, J. Craig, and Stephen J. Scanlan. 2001. "Food Security in Less Developed Countries, 1970 to 1990." American Sociological Review 66(5):718-744.

Johnson, John. 1964. The Military and Society in Latin America. Stanford, CA: Stanford University Press.

Jorgenson, Andrew K. 2003. "Consumption and Environmental Degradation: A Cross- National Analysis of the Ecological Footprint." Social Problems. 50:374-394.

Kaldor, Mary. 1976. "The Military in Development." World Development. 6:459-482.

Kennedy, G. 1974. The Military in the Third World. New York: Scribner.

Kentor, Jeffrey. 1998. "Military Participation, Inequality and Economic Growth: Andreski Was Right." A paper presented at the Annual Meeting of the International Sociological Association: Montreal, Canada. . 2000. Capital and Coercion. New York and London: Garland. 
. 2001. "The Long Term Effects of Globalization on Population Growth, Inequality, and Economic Development." Social Problems. 48(4): 435-456.

. 2004. "Quantifying Hegemony in the World-Economy." In Globalization, Hegemony \& Power: Antisystemic Movements and the Global System, edited by T. Reifer. Paradigm Publishers.

. and Terry Boswell. 2003. "Foreign Capital Dependence and Development: A New Direction." American Sociological Review. 68(2): 301-313.

Kick, Edward L., Byron Davis, and Jeffrey Kentor. 2006. "A Cross-National Analysis of Militarization and Inequality." Journal of Political and Military Sociology. 34(2):319337.

Kick, Edward L., Byron L. Davis, David M. Kiefer, and Thomas J. Burns. 1998. “A CrossNational Analysis of Militarization and Well-Being Relationship in Developing Countries." Social Science Research 27:351-370.

Kick, Edward L. and Bam Dev Sharda. 1986. "Third World Militarization and Development." Journal of Developing Societies 2:49-67.

Kidron, M. 1970. Western Capitalism Since the War. Harmondsworth: Penguin.

Knight, M., N. Loayza, and D. Villanueva. 1996. "The Peace Dividend: Military Spending Cuts and Economic Growth." IMF Staff Papers 43(1):1-37.

Kourvetaris, George A. 1991. "Beyond the Arms Race: The Search for a New Paradigm of a Peaceful World." Journal of Political and Military Sociology 19(2):233-252.

Kurian, George T. 1982. Encyclopedia of the Third World: Vols. I, II, and III. New York: Facts on File, Inc.

Lenski, Gerhard and Patrick D. Nolan. 1984. "Trajectories of Development: A Test of Ecological-Evolutionary Theory." Social Forces. 63(1): 1-23.

Levy, Yagil. 1998. "Militarizing Inequality: A Conceptual Framework." Theory and Society 27:873-904.

Li, Chien-pin. 1997. "Fear, Greed, or Garage Sale? The Analysis of Military Expenditure in East Asia." Pacific Review. 10(2): 274-288.

Lock, Peter and Herbert Wulf. 1977. "Consequences of Transfers of Military-Oriented Technology on the Development in the Third World." Bulletin of Peace Proposals. $8(2): 127-136$.

Looney, Robert. 1988. "Military Expenditures and Socio-Economic Development in Africa: A Summary of Recent Empirical Research." The Journal of Modern African Studies 26: 319-325.

. 1989a. "Internal and External Factors in Effecting Third World Military Expenditures." Journal of Peace Research 26:33-46.

. 1989b. "Impact of Arms Production on Income Distribution and Growth in the Third World." Economic Development and Cultural Change.

. 1990a. "The Policy Relevance of Recent Research on the Economics of Third World Military Expenditures." Journal of Social, Political, and Economic Studies 15:213-223.

. 1990b. "Militarization, Military Regimes, and the General Quality of Life in the Third World." Armed Forces and Society 17:

. and P.C. Frederiksen. 1986. "Defense Expenditures, External Public Debt and Growth in Developing Countries." Journal of Peace Research 23:329-338. 
Lundquist, Jennifer Hickes. 2004. "When Race Makes No Difference: Marriage and the Military." Social Forces. 83(2):731-757.

. 2008. "How Does Job Satisfaction Vary by Gender and Ethnicity in the Military?" American Sociological Review. 87(3).

McKinlay, R. D. and A. Mughan. 1984. Aid and Arms to the Third World. New York: St. Martins Press.

Meyer, John W., John Boli, George M. Thomas, and Francisco O. Ramierez. 1997. "World Society and the Nation-State." American Journal of Sociology. 103:144-181.

Myers, Richard B. 2004. "The National Military Strategy of the United States of America. A Strategy for Today; A Vision for Tomorrow, 2004." Office of the Chairman, Joints Chiefs of Staff. <http://www.defenselink.mil/news/Mar2005/d20050318nms.pdf>

Mills, C. Wright. 1956. The Power Elite. New York: Oxford University Press.

Mintz, Alex and Alexander Hicks. 1984. "Military Keynesianism in the United States, 19491976: Disaggregating Military Expenditures and Their Determination." American Journal of Sociology. 90: 411-417.

Mintz, Alex and Steve Chan. 1991. Defense, Welfare, and Growth. London: Routledge \& Kegan Paul.

Mintz, Alex and Chi Huang. 1991. "Guns versus Butter: The Indirect Link." American Journal of Political Science 35: 738-757.

Mintz, Alex and Randolph T. Stevenson. 1995. "Defense Expenditures, Economic Growth, and the "Peace Dividend": A Longitudinal Analysis of 103 Countries." The Journal of Conflict Resolution. 39: 283-305.

Nestler, Scott T. 2004. "Officer Bloat or Changing Requirements?" Army Magazine: Association of the United States Army. Accessed online at: <http:/www.ausa.org>

Newman, S. 1978. "Security, Military Expenditures, and Socioeconomic Development: Reflections on Iran." ORBIS. 22:569-594.

Pye, Lucian. 1962. "Armies in the Process of Political Modernization." Pp. 69-89 in The Role of the Military in Underdeveloped Countries, edited by J. J. John. Princeton, NJ: Greenwood Press.

Russett, Bruce M. 1969. "Who Pays for Defense?" American Political Science Review 63:2 (June 1969), 412-27.

. 1979. "Disarmament, Human Rights, and Basic Human Needs, Bulletin of Peace Proposals

Samuelson, Paul A. 1979. Economics. 10th ed. New York: McGraw-Hill.

Sanday, Jim. 1991. "The Politicization of Military Professionalism in Fuji." Pp. 239-270 in The Military, the State, and the Development in Asia and the Pacific, edited by Viberto Selochan. Boulder, CO: Westview.

Scanlan, Stephan and Craig Jenkins. 2001. "Military Power and Food Security: A Cross-National Analysis of Less-Developed Countries, 1970-1990." International Studies Quarterly. 45:159-187.

Seiglie, Carlos. 1996. "Exploring Potential Arms Races." Economics and Politics. 8(3): 231-240. . and Liu, Peter C. 2002. "Arms Races in the Developing World: Some Policy Implications." Journal of Policy Modeling 24:693-705.

Sen, Gautam. 1984. The Military Origins of Industrialization and International Trade Rivalry. London: Frances Pinter Pubs, Ltd. 
Senghaas, Dieter. 1977. "Militarism Dynamics in the Contemporary Context of Peripheral Capitalism." Bulletin of Peace Proposals. 8:103-9.

Sivard, Ruth. 1993. World Military and Social Expenditures, 15th edition. Leesburg, VA: World Priorities.

Smith, R. P. 1980. “The Demand for Military Expenditure.” The Economic Journal. 90(360): 811-820

Snyder, David and Edward L. Kick. 1979. "Structural Position in the World Economy and Economic Growth, 1955-1970: A Multiple-Network Analysis of Transnational Interactions." American Journal of Sociology. 84:1096-1126.

Stockwell, Edward and Karen Laidlow. 1981. "The Sociology of Development." International Review of Modern Sociology. 11:145-173.

Stockholm International Peace Research Institute [SIPRI]. 2004. SIPRI Yearbook 2004: Armaments, Disarmament, and International Security. Oxford: Oxford University Press.

Teachman, Jay. 2004. "Military Service during the Vietnam Era: Were There Consequences for Subsequent Civilian Earnings?" Social Forces. 83(2):709-730.

Thomson Corporation. 2008. Journal Citation Reports 2004 - 2007. New York. Thomson Reuters Publishers.

Tilly, C. 1994. "Capitalist Work and Labor Markets. Handbook of Economic Sociology.

Tordaro, M. 1989. Economic Development in the Third World. New York: Longman Publishing.

Trumper, Ricardo and Lynne Phillips. 1997. "Give Me Discipline and Give Me Death: Neoliberation and Health in Chile." International Journal of Health Services. 27:41-55.

U.S. Arms Control and Disarmament Agency. 1989. World Military Expenditures Transfers. Washington, DC: U.S. Arms Control and Disarmament Agency.

Wallerstein, Immanuel. 1974. The Modern World System: Capitalist Agriculture and the Origins of the European World-Economy in the Sixteenth Century. New York: Academic Press.

Ward, Michael D. and David R. Davis. 1992. "Sizing up the Peace Dividend: Economic Growth and Military Spending in the United States, 1948-1996." The American Political Science Review. 86: 748-755.

Weber, Max. 1921 [1968]. Economy and Society. Totowa, N.J.: Bedminster.

Weede, Erich. 1983. "Military Participation Ratio. Human Capital Formation and Economic Growth: A Cross-National Analysis." Journal of Political and Military Sociology. 11:1129.

. 1986. "Rent Seeking, Military Participation and Economic Performance in LDCs." Journal of Conflict Resolution. 30:291-314.

. 1993. "The Impact of Military Participation on Economic Growth and Income Inequality: Some New Evidence.” Journal of Political and Military Sociology. 21:241-258.

Whynes, D.K. 1979. The Economics of Third World Military Expenditure. London: Macmillan.

Wolpin, Miles. 1977. "Military Dependency Versus Mortality Correlates of Economic Development." Population Review 19(1-2):46-50.

Wooldridge, Jeffrey M. 2006. Introductory Econometrics: A Modern Approach, 3rd Edition. Mason, OH: Thomson Southwestern. 


\section{APPENDIX A: COUNTIRES INCLUDED IN THE ANALYSES FOR ALL COUNTRIES (N=67) AND LESS DEVELOPED COUNTIRES $(\mathrm{N}=50)$}

\begin{tabular}{|c|c|}
\hline Algeria & Malawi \\
\hline Argentina & Malaysia \\
\hline Australia* & Mauritius \\
\hline Austria* & Mexico \\
\hline Bangladesh & Netherlands* \\
\hline Bolivia & Nicaragua \\
\hline Botswana & Nigeria \\
\hline Brazil & Norway* \\
\hline Cameroon & Panama \\
\hline Canada* & Papua New Guinea \\
\hline Chile & Paraguay \\
\hline Colombia & Peru \\
\hline Congo, Rep. & Philippines \\
\hline Costa Rica & Poland \\
\hline Denmark* & Portugal* \\
\hline Ecuador & Senegal \\
\hline El Salvador & Singapore \\
\hline Ethiopia & Sri Lanka \\
\hline Finland* & Sweden* \\
\hline France* & Syrian Arab Rep \\
\hline Gambia, The & Tanzania \\
\hline Ghana & Thailand \\
\hline Greece* & Togo \\
\hline Guinea & Tunisia \\
\hline Hungary & Turkey \\
\hline India & Uganda \\
\hline Indonesia & United Kingdom* \\
\hline Ireland* & United States* \\
\hline Israel* & Uruguay \\
\hline Italy* & Venezuela \\
\hline Jamaica & Vietnam \\
\hline Japan* & Zambia \\
\hline \multicolumn{2}{|l|}{ Kenya } \\
\hline \multicolumn{2}{|l|}{ Korea, Rep. } \\
\hline Lesotho & \\
\hline
\end{tabular}

* Denotes countries included in the "all country" sample. 


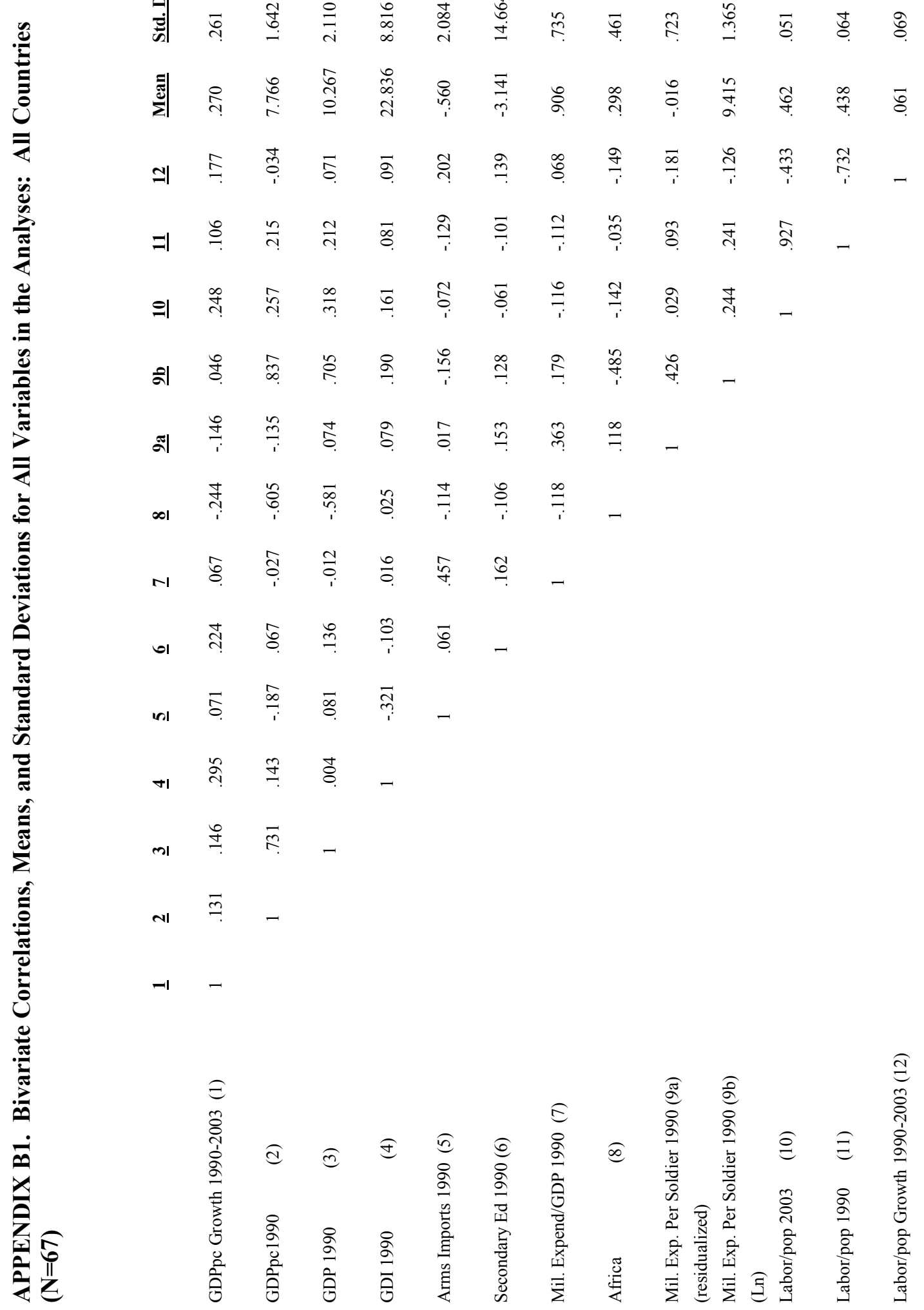




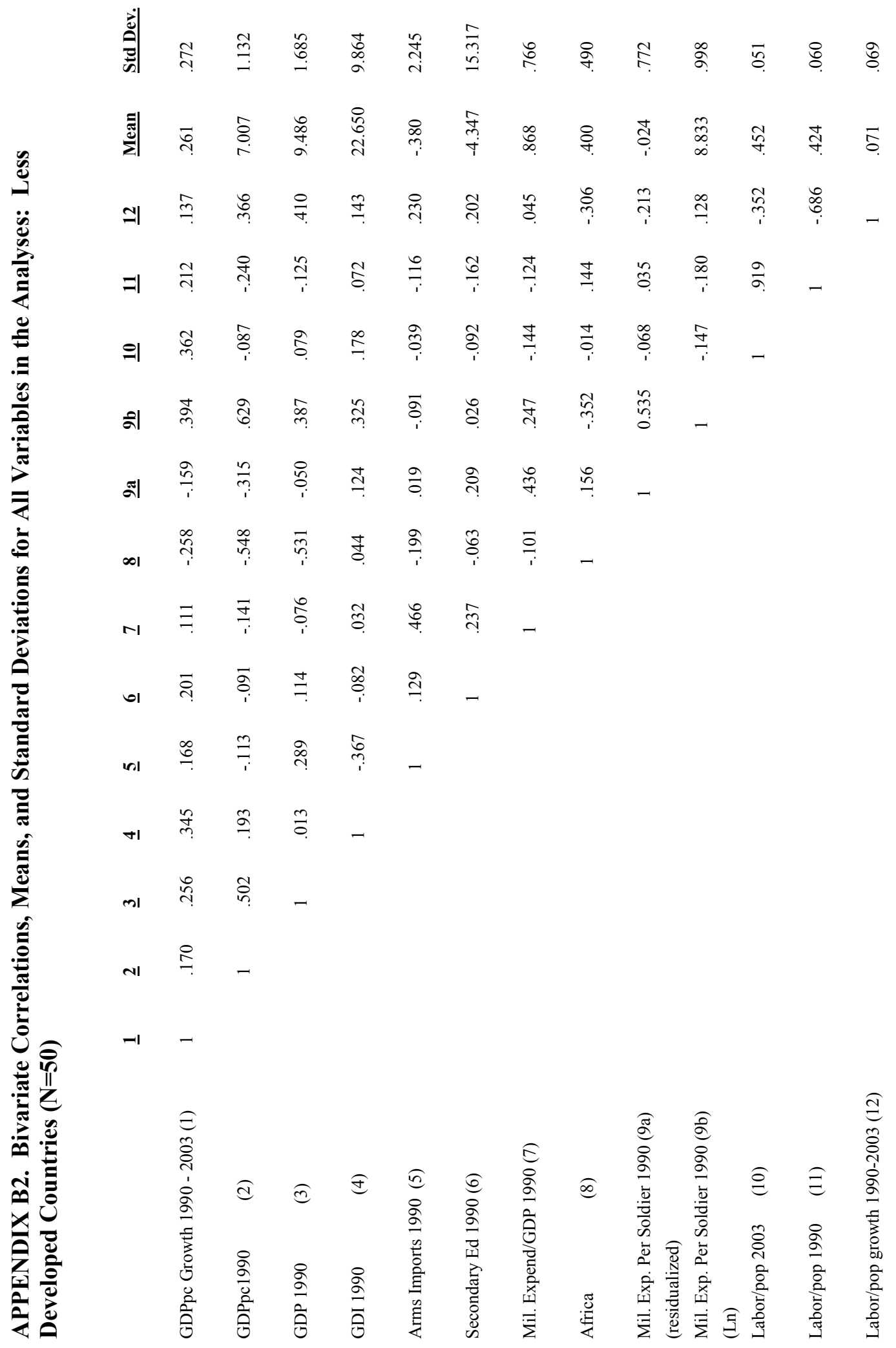


APPENDIX C. Scatterplot of the Relationship Between Military Expenditures per Soldier In 1990 and GDP per capita 2003.

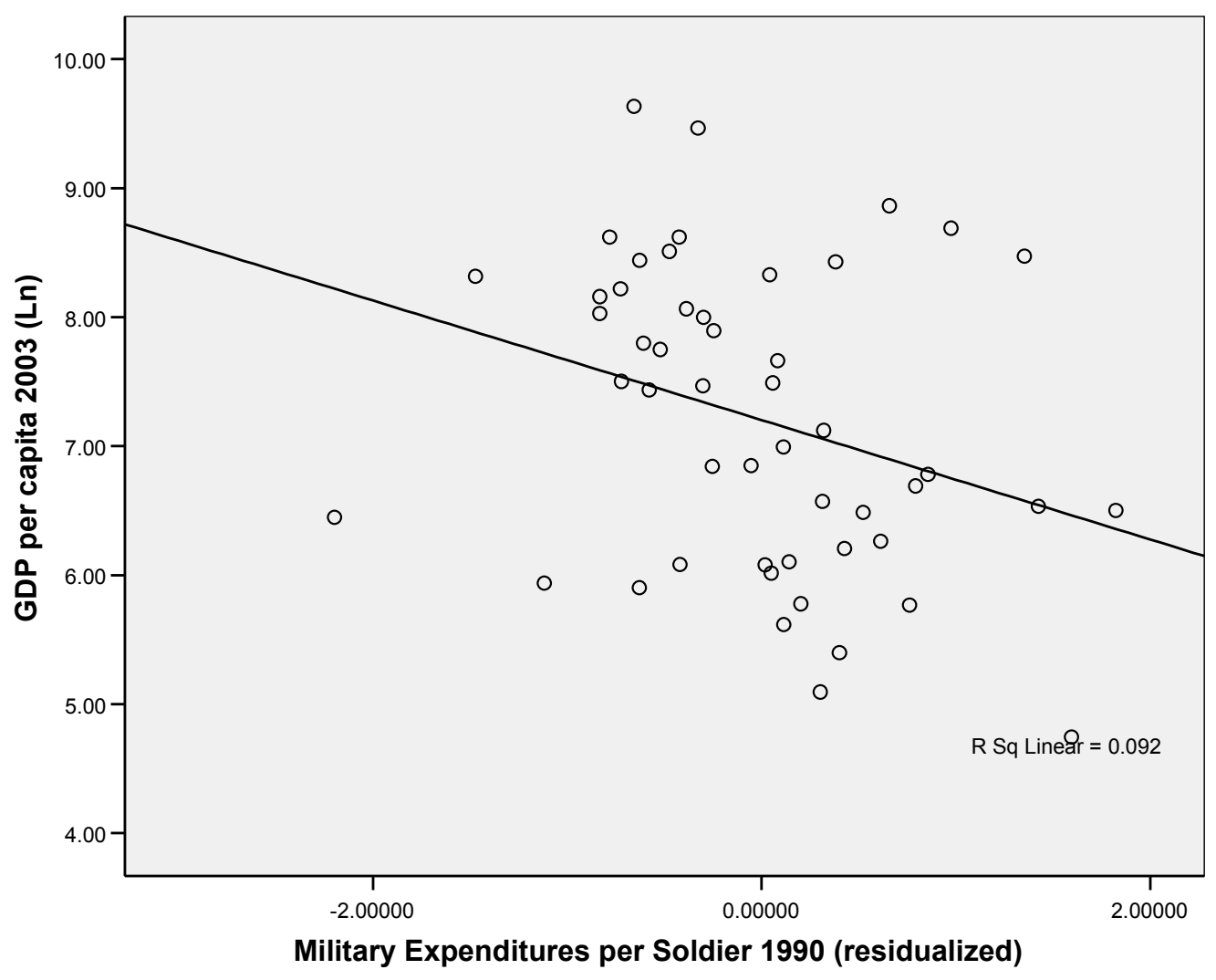



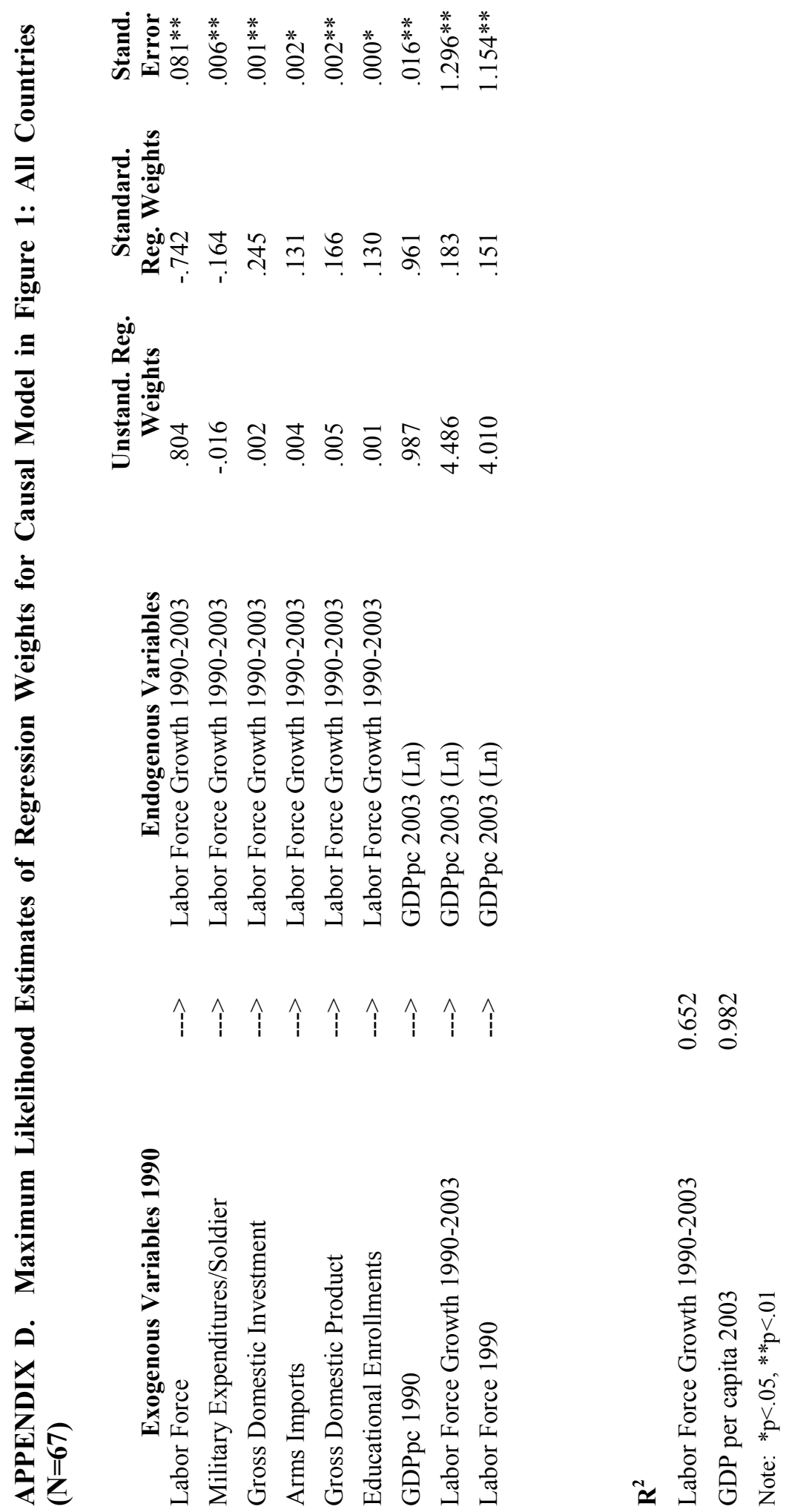


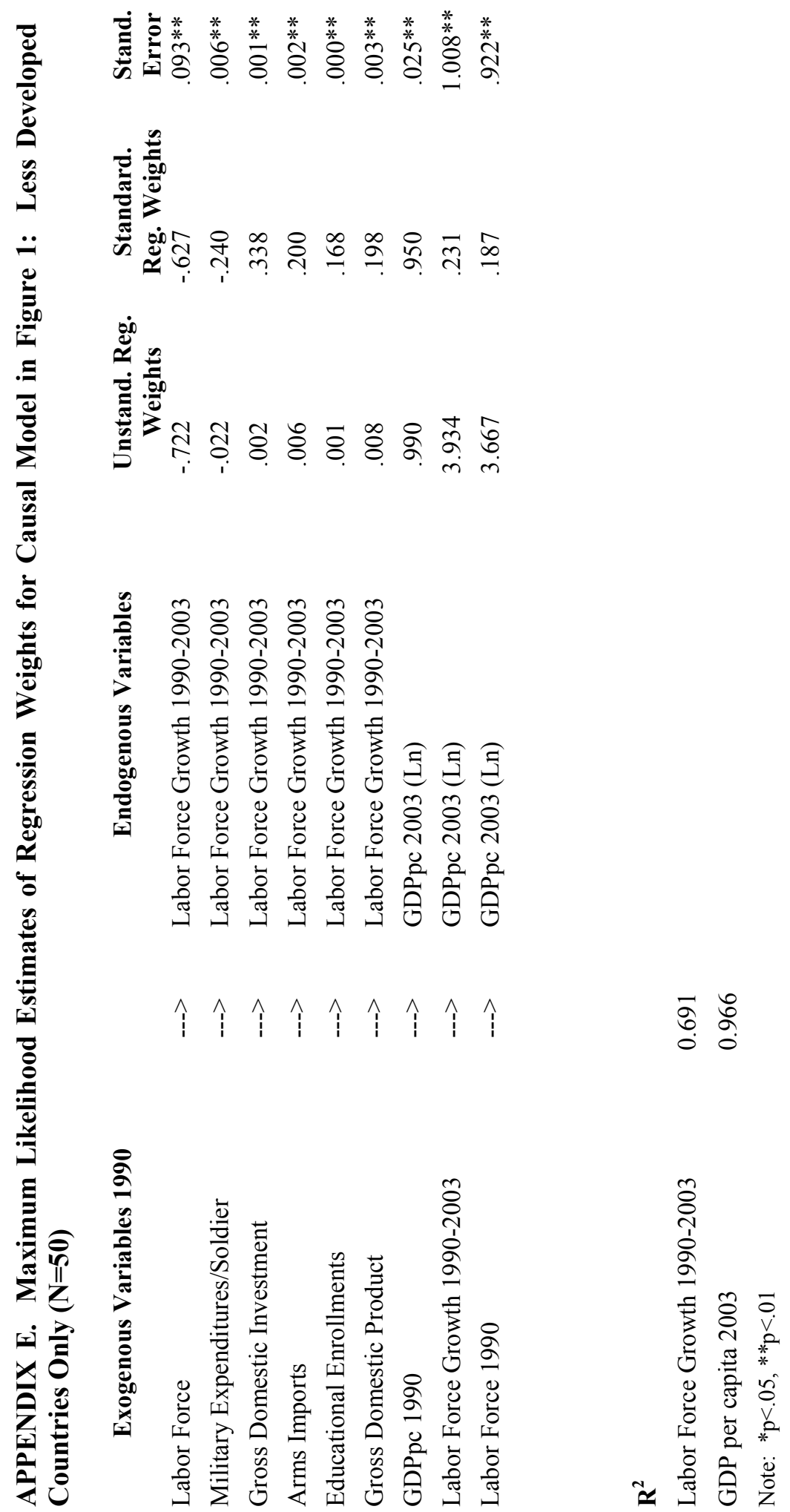

